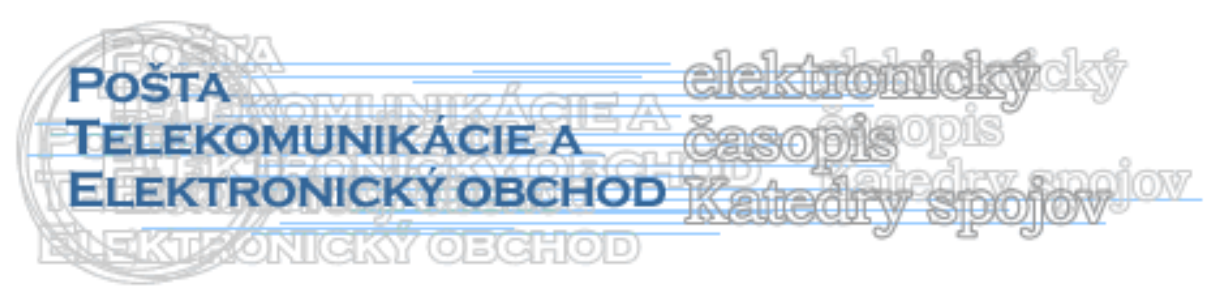

\title{
DOPADY HOSPODÁRSKEJ KRÍZY NA TRH PRÁCE A ZAMESTNANOSŤ V SR
}

\author{
Mariana Strenitzerová ${ }^{1}$
}

\section{Úvod}

„Nemôžeme zabránit' tomu, aby kríza nespôsobovala nezamestnanost'. Ak však budeme konat' hned', môžeme zabránit' zániku pracovných miest a pomôct' miliónom l'udí nájst' novú a lepšiu prácu."

J. M. Barosso , predseda Európskej Komisie

Rozsiahly a hlboký ekonomický prepad, slabá dôvera podnikov v ekonomiku a pokles ziskovosti sa prejavili naprieč eurozónou práve v poklese zamestnanosti. Počas prvých troch mesiacov tohto roku sa v Európskej únii a tiež v eurozóne výrazne znížil počet zamestnaných l'udí. V porovnaní s predchádzajúcim kvartálom roku 2008 ich počet v celej únii klesol o 0,8 $\%$, čo predstavuje takmer 2 milióny. V samotnej eurozóne ich počet klesol tiež o $0,8 \%$, čo predstavuje úbytok o 1,2 milióna pracovných miest.

Úpadok hospodárstva sprevádza strata pracovných miest - v 27 členských štátoch dosiahol počet nezamestnaných $\mathrm{v}$ marci $8,3 \%$ (8,1\% vo februári). 20 miliónov l'udí je $\mathrm{v}$ súčasnosti bez práce, t. j. o 4 milióny viac ako pred rokom. V eurozóne narástla miera nezamestnanosti z 8,7 na $8,9 \%$.

Najhoršie je však pravdepodobne ešte len pred nami. Do konca roku 2010 by mal počet nezamestnaných $\mathrm{v}$ eurozóne dosiahnut' $11,5 \%$, čo je najvyššia hodnota od čias 2 . svetovej vojny.

\section{Analýza situácie na Slovensku}

Nezamestnanost' stúpa rýchlejším tempom od konca minulého roku, prepúšt’anie $\mathrm{v}$ dôsledku hospodárskej krízy ohlásilo viacero firiem. Podl’a informácii Štatistického úradu SR miera nezamestnanosti $\mathrm{v}$ prvom štvrt'roku vzrástla na $10,5 \%$, pričom v poslednom kvartáli minulého roku sa podiel l’udí bez práce znížil na dlhoročné minimum 8,7 \%. Počet nezamestnaných sa v prvom štvrt'roku zvýšil v porovnaní s posledným štvrt'rokom 2008 z 234 000 osôb na 281000 . Miera nezamestnanosti na Slovensku dosiahla v apríli 11,1 \%, čo v porovnaní s marcom predstavuje nárast o $0,5 \%$ (obr. 1)

\footnotetext{
${ }^{1}$ doc. Ing. Mariana Strenitzerová, PhD., Žilinská univerzita v Žiline, Fakulta Prevádzky a ekonomiky dopravy a spojov, Katedra spojov, Univerzitná 1, 01026 Žilina, tel. č.: 041/513 3131, fax: 041/5655 615, e-mail: Mariana.Strenitzerova@fpedas.uniza.sk
} 


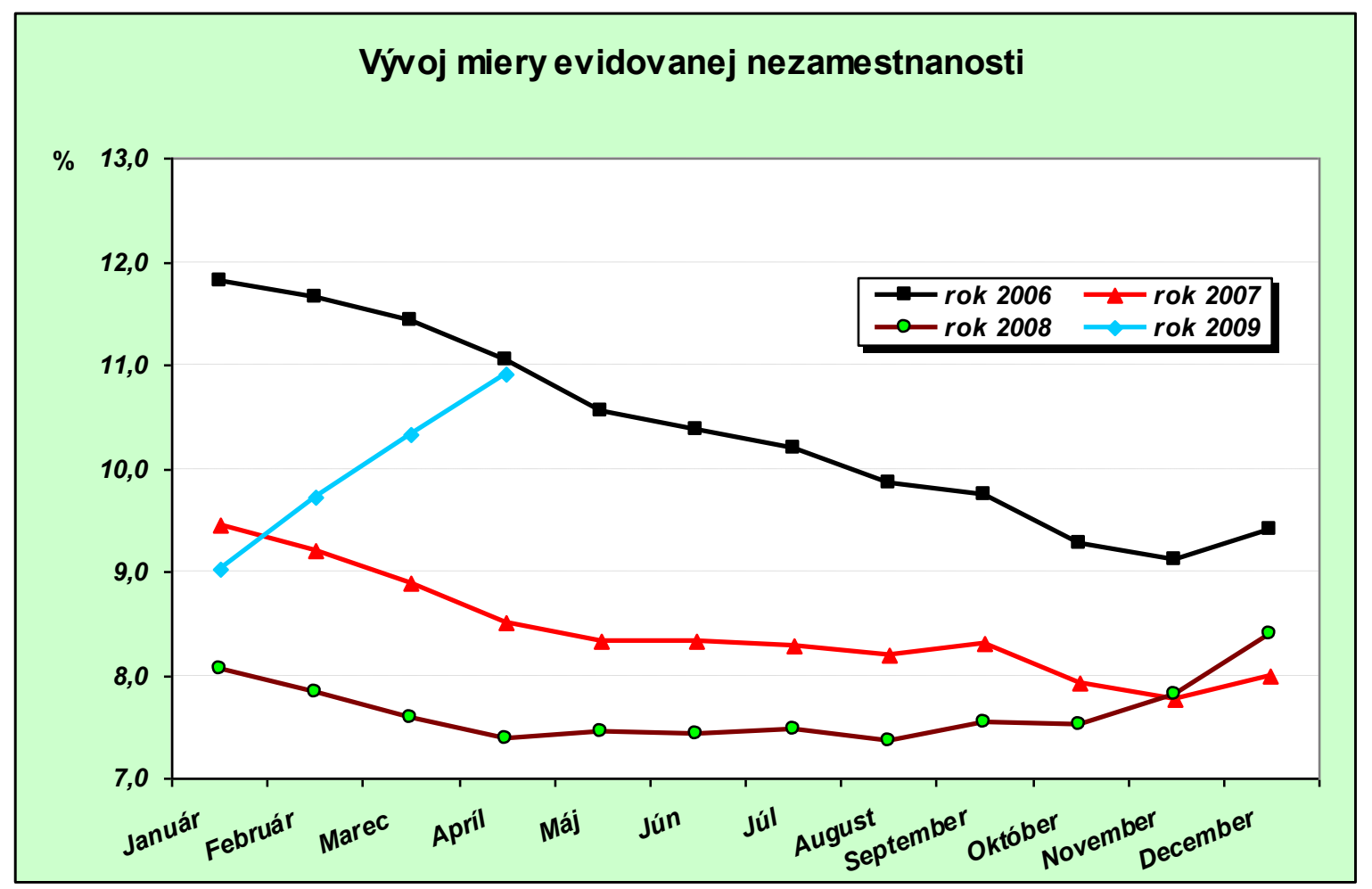

Obr. 1

Naša ekonomika sa bude musiet' vyrovnat' s masívnejším odchodom firiem do lacnejších krajín. Dôvodom odchodov je fakt, že Slovensko sa stalo pre čast' investorov príliš drahou krajinou. Pre tých, ktorí vyhl'adávajú najmä lacnú pracovnú silu, sme sa stali drahými po tom, ako sme vstúpili do eurozóny. Hoci jednotná európska mena je pre našu ekonomiku výhodou, v období krízy môže spôsobit' masívnejší odlev investorov. Vstup do eurozóny má vplyv na konkurencieschopnost' a prináša nám vel'a výhod, avšak len v prípade priaznivého vývoja ekonomických ukazovatel'ov. Kríza výrazne oslabila meny okolitých krajín, a tak v prepočte na euro náklady práce v okolitých krajinách V4 oproti Slovensku výrazne zlacneli. Tento efekt mohol spôsobit' sústredenie výroby najmä do týchto krajín. Pokial' nedôjde k posilneniu okolitých mien, kríza nám spôsobí odlev mnohých investorov. Pokial' firma vyhodnotí, že i po recesii bude mat' dostatok kapacít v iných lokalitách, určite odíde.

Ďalším dôvodom odchodu zo Slovenska je fakt, že uvedeným firmám vyprší čerpanie štátnej pomoci, alebo sú to firmy, ktoré Slovensko lákalo iba z dôvodu nízkych mzdových či prevádzkových nákladov. Najviac sú ohrozené chudobnejšie regióny Slovenskej republiky. Pôsobia v nich totiž firmy, ktoré tam mierili najmä $z$ dôvodu lacnej pracovnej sily, v súčasnosti ich tak lákajú predovšetkým krajiny ako Rumunsko, Bulharsko či Ukrajina. Ide hlavne o firmy, ktorých podnikatel'ský plán je postavený na mimoriadne nízkej pridanej hodnote, ktorá je odkázaná na čo najnižšiu cenu práce. Avšak pre investície s vyššou pridanou hodnotou, bude voči tejto možnosti stát' slovenská kombinácia kvalifikovanej pracovnej sily, stabilného ekonomického prostredia, členstva v eurozóne a zároveň geografickej polohy uprostred strednej Európy, v neposlednom rade daňového režimu.

Ďalším závažným problémom v čase ekonomickej krízy je uplatnenie absolventov a mladých l’udí prichádzajúcich na trh práce zo škôl, ktorí si hl’adajú svoje prvé miesto. Na pár pozíciách, ktoré firmy otvoria v čase krízy, budú očakávat' vysokú kvalitu. Zamestnávatelia v kríze kladú dôraz na výkon zamestnancov a pri výbere ich tak budú 
zaujímat' predchádzajúce skúsenosti a výsledky kandidáta. Zamestnávatelia budú dávat' priestor skôr uchádzačom s praxou, budú prijímat' skôr l'udí prepustených u konkurencie, ktorí nepotrebujú dlhodobejšie zaúčanie, čo môže mat' za následok, že absolventi budú mat' problém uplatnit' sa na trhu práce (obr. 2).

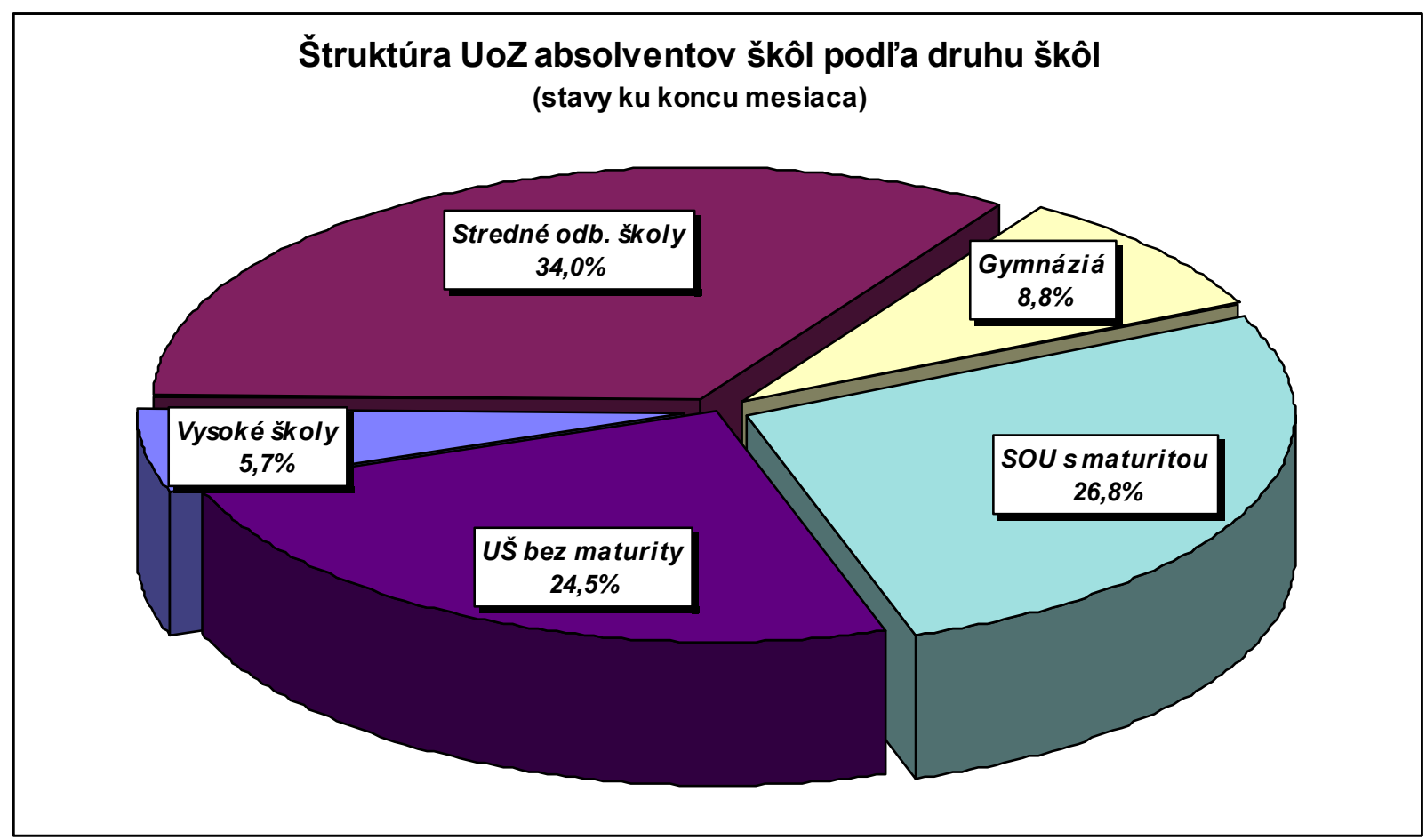

Obr. 2

\section{Opatrenia Európskej únie}

Značne upadajúci pracovný trh je hlavnou hrozbou pre oživenie európskej ekonomiky, a preto zamestnanost' a záchrana pracovných miest sa stali hlavnou prioritou Európskej únie. Európska únia sa snaží využit' všetky dostupné prostriedky, aby zmiernila dosah recesie na pracovníkov. L'ud’om postihnutým krízou je určená podpora z Európskeho sociálneho fondu a Európskeho fondu na prispôsobenie sa globalizácii.

Komisia navrhuje okamžité uvol'nenie prostriedkov do výšky 19 mld. eur z účelových fondov na boj proti rastu nezamestnanosti následkom recesie. Návrh je súčast'ou akčného plánu pre zamestnanost', ktorý takisto navrhuje vyčlenit' 500 mil. eur na mikroúvery pre začínajúcich podnikatel'ov a rozšírenie odbornej praxe pre mladých l'udí.

Prostriedky vo výške 19 mld. eur pochádzajú z programov sociálneho fondu EÚ na podporu zamestnanosti a zníženie rozdielov v životnej úrovni. Na obdobie rokov 2007 až 2013 vyčlenila EÚ do fondu 77 mld. eur, t. j. približne $10 \%$ svojho celkového rozpočtu. S ohl'adom na rast nezamestnanosti chce Komisia urýchlit' čerpanie fondov s ciel'om pomôct' l’ud'om postihnutým krízou. Navrhuje, aby sa upustilo od obvyklej požiadavky spolufinancovania zo strany členských štátov.

Prostriedky zo skoršieho čerpania by sa mali použit’ na rekvalifikáciu pracovníkov, na pomoc pri hladaní zamestnania a rozbehnutie vlastného podnikania. Vlády by mohli prostriedky takisto použit' na kompenzáciu zníženia príjmov pracovníkov v dôsledku krátenia 
pracovného času pre pokles objednávok ich zamestnávatel'ov. Vel’a členských štátov EÚ podporuje krátkodobé práce, aby stovky tisícov pracovníkov nestratili prácu $\mathrm{v}$ čase hospodárskeho útlmu.

S pomocou Európskej investičnej banky navrhuje Komisia zriadit' mechanizmus s rozpočtom 500 mil. eur na poskytovanie mikroúverov pre l'udí odhodlaných začat's vlastným podnikaním. Takmer 100 mil. eur pre tento mechanizmus sa získa presmerovaním prostriedkov $\mathrm{z}$ existujúcich fondov.

$\mathrm{V}$ rámci pomoci pre mladých l'udí uplatnit' sa na trhu práce sa Komisia usiluje o to, aby sa spoločnosti v celej EÚ zaviazali prijat' o 5 miliónov viac čerstvých absolventov a stážistov. Nezamestnanost' mladých Európanov (pod 25 rokov) sa vyšplhala na $17 \%$, čo je dvojnásobok priemernej hodnoty.

Plán sa zasadzuje za okamžitú pomoc nezamestnaným s argumentom, že $\mathrm{s}$ narastajúcou dížkou nezamestnanosti sa skracujú šance na opätovné uplatnenia na trhu práce. Nezamestnaní by mali začat' odbornú prípravu alebo iné zamestnanie čo najskôr - v prípade mladých l'udí vo veku do 20 rokov do 1 mesiaca, u l'udí vo veku od 20 do 25 rokov do 2 mesiacov a v prípade l'udí vo veku nad 25 rokov do 3 mesiacov od prepustenia.

EÚ čelí najhoršej recesii za posledné desat'ročia. Očakáva sa, že monetárne a fiškálne stimuly by mali zabrat' $\mathrm{v}$ budúcom roku, ale dovtedy príde $\mathrm{v}$ hospodárstve o prácu 8,5 milióna l'udí. Do konca roku 2010 by mal počet nezamestnaných v eurozóne dosiahnut' 11,5 \%, čo je najvyššia hodnota od čias 2 . svetovej vojny.

Podnikom bola adresovaná výzva, aby uprednostnili skrátenie pracovného času pred okamžitým prepúšs'aním zamestnancov, ktorí by takto získaný čas mohli využit' na rekvalifikáciu. Niektoré spoločnosti, najmä v Nemecku, už túto prax aplikujú.

Podniky by mali takisto zamestnávat' viac učňov a stážistov, čím by mladým l’ud’om pomohli získat' základy na pracovnom trhu. Týka sa to predovšetkým absolventov stredných a odborných škôl. Miera nezamestnanosti medzi mladými Európanmi do 25 rokov už prekročila hranicu $17 \%$, čo je dvakrát viac ako celková miera nezamestnanosti a očakáva sa, že v niektorých krajinách EÚ presiahne $30 \%$. Odborná príprava by sa mala zamerat' na znalosti a zručnosti, po ktorých je najväčší dopyt.

Mladí a nezamestnaní by mohli ostat' produktívni aj vd'aka väčšej podpore pre začínajúcich podnikatel'ov.

\section{Návrh odporúčaní pre firmy na Slovensku}

Personálne agentúry hlásajú dve protichodné tendencie svojich klientov. Na jednej strane niektoré výrobné podniky, ktoré znižujú výrobu, prednostne prepúšt’ajú agentúrnych zamestnancov, čo je ovel'a jednoduchšie ako rozviazat' trvalý pracovný pomer. Na strane druhej sú firmy, ktoré výrobu neznižujú, ale nie sú si isté, aký bude d’alší vývoj ekonomiky, a tak dávajú prednost' práve agentúrnym zamestnancom, pretože táto pracovná sila je ovel'a flexibilnejšia.

Firmy sa snažia šetrit', a to aj v oblasti human resources. Obmedzenie investícií sa týka hlavne náboru nových pracovníkov. Firmy uplatňujú dve riešenia, jednak znižovanie odmien, platov a benefitov, ale taktiež prepúšt'anie drahej pracovnej sily. Úspory v oblasti l'udských zdrojov sa však nemusia vzt'ahovat' len na obmedzovanie pracovných pozícií. Tie si najlepšie udržia lojálni zamestnanci, ktorí pracujú v jednej firme čo najdlhšiu dobu. Zamestnanci si to uvedomujú, ako je vidiet' zo znižujúcej sa fluktuácie. Aj stálych a lojálnych zamestnancov, 
ktorí o svoje miesto neprídu, sa ale úsporné opatrenia dotknú, ktoré však predstavujú len dočasné spomalenie rastu priemerných miezd.

Ďalšia položka, ktorá sa dotkne zamestnancov je možné krátenie alebo dočasné prerušenie vyplácania benefitov, odmien a prémií. Firmy tak môžu usporit' nemalé financie. Zamestnávatel' by však mal citlivo vysvetlit' situáciu zamestnancom, s tým, že tento postup aj im dáva určitú istotu, že o prácu neprídu. Obmedzenie výdavkov, ktoré sa priamo dotýkajú zamestnancov, je možné aj v oblasti d'alších benefitov (príspevky na dôchodkové poistenie, životné poistenie, zdravotné a relaxačné pobyty, príspevky na dovolenku, športové aktivity, kultúrne programy a pod.).

Efektívne riešenie v prípade, že si chce firma udržat' svojich kvalitných zamestnancov, ale potrebuje obmedzit' výdaje, je obsadit' nižšie pozície zamestnancami, ktorí zaujímajú vyššie miesta. Špičkoví pracovníci sa hl'adajú náročnejšie, dlhšiu dobu a ich zaškolenie je výrazne drahšie ako u tých na nižších či stredných pozíciách. Toto dočasné opatrenie môže priniest' výhody obidvom stranám: zamestnanec má istotu pracovného miesta a zamestnávatel' nestratí ani zamestnanca, ani investície, ktoré do neho vložil, a naviac ušetrí na prijímaní nových pracovných síl.

Ďalšie možné úspory sa však nemusia týkat' len interných zamestnancov, ale taktiež externých, či dokonca outsourcovaných služieb a oblastí, čiastočných obmedzení investícií do PR a reklamy, oblasti inovácií a to vo všetkých zložkách podnikového fungovania.

\section{Európske služby zamestnanosti (EURES) na Slovensku}

Od vstupu SR do EÚ, teda od 1. mája 2004 začala aj na Slovensku fungovat' siet' EURES. Uchádzači v nej môžu nájst' databázu vol'ných pracovných miest, ktoré sú k dispozícii vo všetkých členských krajinách EURES. Súčast’ou siete je všetkých 27 členských krajín EÚ, kandidátske krajiny i krajiny Európskeho ekonomického priestoru - Nórsko, Island, Švajčiarsko a Lichtenštajnsko. Poskytuje aj informácie o pracovnom trhu d'alších krajín, ktoré sú pre Slovákov zaujímavé.

Systém EURES je zameraný na ul'ahčovanie vol'ného pohybu pracovných síl v rámci krajín Európskeho ekonomického priestoru (krajiny EÚ + Nórsko, Island, Švajčiarsko, Lichtenštajnsko). Má slúžit' nezamestnaným i záujemcom, ktorí si hl’adajú prácu v zahraničí. Partnermi tejto siete sú verejné služby zamestnanosti jednotlivých krajín, odborové a zamestnávatel'ské organizácie. Partnerstvo koordinuje Európska komisia.

Siet' EURES pre uchádzačov o zamestnanie poskytuje:

- informácie o vol'ných miestach v jednotlivých členských krajinách, o prechodných obdobiach, o trhoch práce v jednotlivých krajinách;

- asistenčné služby pri hl'adaní si zamestnania. EURES pracujú s databázou vol’ných pracovných miest a životopisov uchádzačov o zamestnanie. Pracuje sa i na vytvorení systému automatického párovania vol'ných pracovných miest a vhodných životopisov;

- poradenské služby pri tvorbe žiadostí o zamestnanie, poradenstvo pre klientov $\mathrm{v}$ prihraničných oblastiach.

zahraničia.

Pre zamestnávatel'ov EURES poskytuje pomoc pri hl'adaní zamestnanca zo

\section{Záver}


Trvanie krízy je stále vel'kou neznámou. Akým smerom sa bude situácia na Slovensku uberat', nevie jednoznačne povedat' nikto. Podl'a niektorých ekonómov je úplné dno už za nami, podl'a iných nás ešte len čaká. Európska únia očakáva dno krízy až v tret’om kvartáli. Niektoré indikátory naznačujú, že mierne zlepšenie by malo príst' v druhej polovici tohto roka. Počet l'udí bez práce na Slovensku však zatial' len porastie.

\section{Literatúra}

[1] METODIKA ŠU SR . 2009 [Online]. Dostupné na: http://portal.statistics.sk

[2] NEZAMESTNANOSŤ. Demografia, vzdelanie a životná úroveň [online].[s.a.] Dostupné na: http://www.sazp.sk

[3] ZAMESTNANOSŤ A SOCIALNA POLITIKA. 2009. [online] Bratislava, Mesačník ústredia práce, socialnych vecí a rodiny a ministerstva práce ,socialných veci a rodiny SR, Dostupné na: http://www. upsvar.sk

[4] Denník Hospodárske noviny

[5] Moderní ř́zení. Časopis vydavatel'stva Economia. 